\title{
Inglorious Empire - A Critical Reading
}

\section{Inglorious Empire: What the British did to India}

Shashi Tharoor, 2017

London, England: C. Hurst \& Co. (Publishers) Ltd.

196 pp., ISBN $9781849048088, £ 15.41$

Reviewed by

Tikaram Poudel*

Kathmandu University School of Education, Lalitpur, Nepal

In Inglorious Empire: What British did to India, Shashi Tharoor, an eminent politician and a writer, tells the story of colonial exploitation of the Indian SubContinent from an eye of a colonised subject. I call the perspective a Post-Colonial one. The objective of the book is well expressed by the author towards the end of the book, 'History belongs to the past; but understanding it is the duty of the present'. He performs this duty of understanding the history of the British Raj in eight different chapters of this book.

Unlike the usual expectation of academic work, Inglorious... opens abruptly as if the author is in a hurry, to tell us how the British deindustrialised India; how they looted the enormous wealth; and how they exploited her people morally and spiritually. In this process of deindustrialisation, loot and exploitation, Tharoor meticulously tells the story of the Raj's destruction of the textile industries of the Sub-Continent by imposing enormous taxes to local textile industries; the story of how the Raj made the youths of the land fight for white Empire; and the story of the annihilation of the shipbuilding and steel industries of India that had flourished for millennia. Consequently, they killed the

* Reviewer Email: tikaram.poudel@kusoed.edu.np

https://orcid.org/0000-0002-6963-7013
ISSN: 2091-0118 (Print) / 2091-2560 (Online)

(C) 2019 The Reviewer(s).

${ }^{2}$ https://www.nepjol.info/index.php/JER/index

Published by Kathmandu University School of Education, Lalitpur, Nepal.

This open access article is distributed under a Creative Commons Attribution (CC BY-SA 4.0) license. 


\section{Inglorious Empire - A Critical Reading | 119}

genius of the Sub-Continent; the creativity of textile workers, the art of shipbuilding and steelworks. These age-old indigenous scientific and technological innovations that flourished in the Sub-Continent died out from the human knowledge system forever.

The deindustrialisation slumped the economy of the Sub-Continent. The intensity of economic exploitation during the $R a j$ can be imagined with the fact that the Britons made the peasants sell their children to pay the taxes. In a light-minded tone, Tharoor argues that the British borrowed the word 'loot' from Indian languages and made their own because it described their true nature. However, the colonial meta-narrative defended the deindustrialisation, economic exploitation and human infliction with the argument that traditional Indian industries of textile, shipbuilding and steel could not compete with the Industrial Revolution of the West.

In Chapter Two, Tharoor argues against the colonial meta-narrative that the $R a j$ conquered the fighting principalities and contributed to the making of India as a nation. Tharoor argues that, unlike the European conception of the nation, the Indian concept of nation is not a political but the common cultural heritage such as the essence of the epics like the Ramayana and the Mahabharata. Spirituality is another deep-rooted canon of nationhood popularised by sages like Shankaracharya, in seventh century AD. Establishing the places of worship from Kerala to Kashmir and from Dwarka to Puri, Shankaracharya gave the message of the cultural uniqueness of India much higher than the European notion of nationhood.

The British used the concept of 'nation' to exclude the people of the Sub-Continent from honour and dignity. The indigenous people did not qualify for higher positions in government service but they were never ineligible for the payment of taxes and other forms of exploitations. The principles of exclusion enabled the British to rule the people with such self-confidence that a few hundred of them dominated the entire SubContinent with utter despotism. The principle of exclusion established them a superior race, superior military technology and the mystique of modernity. The British learned this from their philosophical movement of Enlightenment humanism. In the name of Enlightenment humanism, cupidity and opportunism prevailed to sustain the Empire and vanquished the civilisation that flourished for thousands of years.

Racism as an instrument of exclusion as portrayed in the imperial literature e.g., Rudyard Kipling and E M Foster established the White as a demi-god and the 


\section{$120 \mid$ T. Poudel}

indigenous as semi-native. These literary texts portrayed the local people as 'brute passions', 'untamed beasts'; the White made these 'brutes' and 'beasts' fight for the Empire, lost their life but to be recorded for their heroism; they never became the part of popular British stories.

In Chapter Three, Tharoor takes the way Indian history has been taught in Indian schools. Majority of Indian textbooks claim that the Raj introduced the concept of free press and rights of free citizens that enabled the institution of democracy in India. Tharoor agrees that free press played a pivotal role in uniting people during the freedom movement, however, the strict restrictions on the press during the $R a j$ never gave people the conceived freedom. In the later part of the Raj, newspapers catered for about $10 \%$ literate Indians. The published information used to spread by word of mouth and it was not unusual in a country with a rich oral tradition.

Tharoor argues that the British had no intention of establishing democracy in India; Indians chose the parliamentary system through a Constituent Assembly. The parliamentary system of democracy was not a gift of the British to India but it was the choice of the framers of the Constitution of India; the majority of them were educated in Britain and this British legacy is still common in Indian Parliament. The truth was that to perpetuate the Empire, they established a dominant discourse of 'rule of law'; in the name of 'rule of law', a British concept alien to the Indian cultural system, the British discriminated Indians with severe punishments for petty crimes. Through this so-called 'rule of law', the British sustained and strengthened colonialism through their brutal technologies. The British redefined and understood the fluid Indian society for their own satisfaction without paying heed to Indian rules and customs.

Chapter Four explores the way the British intervened Indian social system to turn it suitable for the Empire. In the process of perpetuating the Empire, the British also misunderstood the Indian caste system and used it for social categorisation. Indian society never ran through written rules but jati or biradari settled every dispute through unwritten norms and common sense. The British used Indian caste system and ethnic diversity for racial classification, a colonial strategy to control over the colonised. Because of the literate traditions of the Brahmins, the British used them as their intermediaries for indicting exploitation of the peasants and artisans, further instilling hatred towards Brahmins from non-Brahmin communities. This policy intensified the 
Inglorious Empire - A Critical Reading | 121

differences among the communities preventing the unity of ethnic groups and justified the British rule forever. In addition to the caste system and ethnic diversity, the British deliberately divided the Hindus from Muslims for their political gain culminating during the partition.

British and German scholars such as Mill, Macaulay and Max Mueller theorised that the Brahmins were descendants of Aryans, who invaded the Indo-Gangetic plains about 1500 BCE coming from Caucasus region of Central Asia. These Aryans drove the Dravidian speaking population away to the southern plateau and enslaved local ethnic communities. On the other hand, the Muslims came in waves to invade and plunder the rich principalities of Hindu populations. Under British patronage, both Hindu and Muslim revivalists intensified respective spiritualism of their religions and this served the purpose of the Empire. This propagandist spiritualism under the British patronage was against the true spirit of Indian society.

A closer look at the historical development of the British people reveals that they were never spiritual people but a fighting and commercial race. This collective racist disposition of the British people gets expression in representative British figures. For example, Winston Churchill said, "I hate Indians. They are a beastly people with a beastly religion" (Selby, 2015, para. 7). This collective disposition of the British is manifested in the popular literature, for example, the portrayal of Caliban in William Shakespeare's The Tempest, of Friday in Daniel Defoe's Robinson Crusoe, Rudyard Kipling's notorious colonial poem White Man's Burden, to name a few.

Despite such a racist ideology, the British people have been presented to Indians as 'essentially benign' as the true children of Enlightenment humanism. Chapter Five reveals this myth of the benign nature of the British. About 35 million people of the Sub-Continent lost their life in the 20th century. The British refused to intervene to save the lives of millions because, for the British, famines were the ways that nature responded to overpopulation, according to Malthusian principles. Instead, they argued that all Indians would be dying of starvation if there had not been the benevolence of the Raj. But nobody told the boys and girls in India that while Indians were dying of starvation, the British were enjoying Indian bread in London and Manchester.

The discourse of benevolence is exposed through the stories of Indian men and women i.e., colonial workforce, who were enslaved and transported in British ships to 


\section{$122 \mid$ T. Poudel}

Africa and other Pacific regions. The benevolence of the Raj did not end with humaninduced famines and enslavement of Indian men and women, the Raj ordered General Dryer shoot at thousands of children, women and men at Jallianwala Bagh in 1919.

After exploring the racial instincts of the British in Chapter Five, in Chapter Six, Tharoor takes up the issues of racial discrimination in infrastructure development, particularly railways and education. The British constructed the Indian railways to transport raw materials for British industries and to transport the finished products of British industries to Indian markets. Since the railways enabled British businessmen to transport goods faster and in larger quantities, they converted the previously forested land into agricultural farmlands to feed their giant industries back home in England. The conversion into farmlands caused severe environmental imbalance as this process intensified the destruction of the habitat of different wildlife and plants. Besides, the British forced millions of Indian men and women in these newly converted farmlands. For millennia, these people owned the forest and lived sustainably without causing an environmental disaster. For the British, the forest land belonged to nobody i.e., terra nullius because the indigenous communities could not produce the certificates of land registration. The coming of the railways turned these communities to slaves from the masters of their lands.

The railways caused multiple sufferings to Indian peasants in many ways. To finance the construction of railways, people of India were made to pay high taxes leading to utter poverty. The arable land of Indian peasants, for example in the Bengal Delta, turned into marshy land because it blocked the waterways. The railways were also the causes for epidemics like the Bubonic Plague of 1897 killing estimated 12 million Indians (Malhotra, 2020) of total 180-200 estimated population and Spanish Flu in 1918 killed an estimated 12 million Indians of estimated 300 people. These epidemics first appeared in port cities and spread to inner cities through railways.

Anglophile historians of India established the discourse that Britain gave the SubContinent the English language that played a key role in establishing the roots of democratic values. However, the truth is that the democratic values that India developed were through the process of resisting the despotism of the Raj, not importing the democratic values from Britain. 
Inglorious Empire - A Critical Reading | 123

The English language is not a deliberate gift to the Sub-Continent but it came as an instrument of colonialism. The true intention of the introduction of the English language in the educational system of the region is clearly stated in the notorious minute of Macaulay of 1835, the foundational document to determine the future course of education in South Asia. The British intended to facilitate communication with natives through the English language to serve the interest of the Empire. However, the leaders of the freedom movement seized the English language and used it to fight against the Raj.

Teaching indigenous languages like Sanskrit or Arabic or teaching Indian history and philosophy was never prioritised during the Raj. The British needed an army of young Indians for the service of Empire and they could not think of preparing this army imparting education in indigenous languages. The objective of colonial education was to serve the purpose of the Empire, not general human welfare; therefore, they never intended to dispense higher human values through universal education. During the colonial period, British education did not focus on promoting analytical and creative thinking leading to the independence of mind. A limited number of the graduates in this system excelled, entered Indian Civil Services, got westernised and alienated themselves and became hybrid because of their proximity with their white masters. Therefore, the impact of colonialism was not merely economic and political but also moral, intellectual and spiritual. It was not just a physical conquest but a conquest of mind and soul. By imposing the colonial ideology through education, the Raj attacked the very core of Indian cultural and spiritual heritage and forced them to imitate the English. This education distanced the Indian youths from the religious and mythological teaching of the region like the Ramayana and the Mahabharata. Rejecting the indigenous knowledge system and integration of English literature as a subject in the curriculum was to instil a feeling of respect to British civilisation in the hearts of colonised minds.

In Chapter Seven, Tharoor tells the story of how the British attempted to annihilate one of the oldest and most vibrant civilisations of the world and lay the foundation of western values in the region. In the process of annihilation, the British devastated the socio-economic structure leading to the literacy rate of 16\%, a life expectancy of 27 and $90 \%$ of the population living below the poverty line when they left in 1947 . Tharoor 


\section{$124 \mid$ T. Poudel}

argues that the region that created and developed the wisdom of Vedas and Upanishads did not have to look for colonial values to regenerate from the abyss of the Raj.

In Chapter Eight, Tharoor regrets that the elites, the 'mimic men' of Naipaul, continue the imperial power even after the political decolonisation. Every conscious individual of the region today understands the $R a j$ as a British project for dictatorship, extermination, slavery. These two hundred years of the $R a j$ prepared us for the strongest weapon of resistance with the realisation that we can defeat the enemy of hatred with the weapon of soul force. These two long centuries also enabled India to teach the world to fight hatred with the weapon of non-violence.

The Inglorious...is a story of colonial exploitation; the author is a true child of colonialism. He is more interested in the colonial vocabulary and he forgets that he is writing to an audience of the second decade of the 21 st century. Unfamiliar words such as xenolatry, autarky, apotheosis, etc. make the reading completely alien to young readers. If I were writing this book, I could have avoided clumsy long sentences that run beyond the normal processing speed of our brain. While reading the text, a conscious reader often feels that the author has too much information but fails to organise them. He could have led the readers through the panoramic view of human suffering that he intended to make the reader experience. Despite these flaws, the Inglorious ... is an eyeopener to every enthusiastic reader interested in understanding the collective past of the region.

\section{References}

Malhotra, A. (2020, April 26). When the 1897 bubonic plague ravaged India. Retrieved from https://shorturl.at/fhlAE

Selby, J. (2015, January 30). Winston Churchill: Accusations of anti-Semitism, economic inexperience and the blunt refusal that led to the deaths of millions. Retrieved from https://bit.ly/2AB9M8d

\section{To cite this article:}

Poudel, T. (2019). Book review: Inglorious empire - A critical reading. Journal of Education and Research, 9(2), 118-124. https://doi.org/10.3126/jer.v9i2.30466 